\title{
Media practices in the Brazilian mobilizations of $2013^{1}$
}

\author{
Ana Cristina Suzina \\ Comuni - Núcleo de Estudos de Comunicação Comunitária e Mídia Local, Brasil - anasuzina@hotmail.com
}

\begin{abstract}
This article discusses how a series of national mobilizations in Brazil, in 2013, embedded a relevant debate around the social judgment regarding journalistic practices and a consequential "desire of reform" towards an "ideal journalism". I will also discuss the assumption that community and alternative media help, on a regular basis, to develop journalism and improve democracy. The reflection is

consists in the observation of the evolution of mainstream media covering during the protests, through the analysis of the front pages of the newspaper Folha de S. Paulo. The second refers to the inclusion of claims related to media in the demonstrations and its roots in the struggles for media democratization in the country, and counts on interviews with 11 Brazilian media activists.
\end{abstract} based on a two-step approach. The first step

Keywords: protest, media, activism, Brazil, democracy.

\section{Práticas mediáticas durante as manifestações brasileiras de 2013}

\section{Sumário}

Este artigo discute a forma como uma série de manifestações nacionais no Brasil, em 2013, embutiu um debate relevante em torno do julgamento social em relação às práticas jornalísticas e um consequente "desejo de reforma" em direção a um “jornalismo ideal”. Também discute a hipótese de que os media comunitários e alternativos contribuem, regularmente, para desenvolver o jornalismo e a melhorar a democracia. A reflexão é baseada numa abordagem em duas etapas. A primeira delas consiste na observação da evolução da cobertura mediática sobre os protestos, por meio da análise das primeiras páginas do jornal Folha de S. Paulo. A segunda etapa refere-se à inclusão de reivindicações relacionadas com os media nas manifestações e às suas raízes nas lutas pela democratização dos media no país, e se fundamenta em entrevistas com 11 mediativistas brasileiros.

Palavras-chave: protesto, media, ativismo, Brasil, democracia.

1 The data analyzed in this article was collected within a doctoral research financed by CAPES/Brazil. 


\section{INTRODUCTION}

In June of 2013, more than three million Brazilian citizens went to the streets of around 140 cities all over the country, in a series of demonstrations that were later denominated as the Journeys of June (Secco, 2013). It all begun with a regular demonstration organized by Movimento Passe Livre (MPL) against the increment of 20 cents in the price of the transport ticket in the city of São Paulo.

As Lincoln Secco describes ${ }^{2}$,

The two first acts followed the traditional MPL's capacity of mobilization for street demonstrations (around two thousand people). The fourth act kept still small, but the repression coming from the police triggered a wave of solidarity towards MPL that was able to bring about 250 thousand people to the following act. (Secco, 2013, p. 73)

The series of protests of 2013 joined a large wave of massive mobilizations around the world and became a turning point in the Brazilian recent history, with controversial frameworks of analysis (Bringel \& Pleyers, 2015). Part of the interpretations recognized the appropriation of the streets and of the political debate by the people - following the celebrated perception that "the giant has woken up", suggested on online and offline posters. Another part took different perspectives that highlighted an appropriation of the popular movement by right wing actors, identifying a fascist threat, and even finished by reading the protests as the birth place of the movement that led to the results of 2018 elections.

Breno Bringel and Geoffrey Pleyers summarize that the Journeys of June represented "a new cycle of protest, a reconfiguration of civil society and the emergence of entrenched political subjects in another conception of democracy" (Bringel \& Pleyers, 2015, p. 11). The authors insert the mobilizations in a larger historic cycle and discuss how a viral diffusion of a transversal agenda has reached millions of citizens and triggered transformations that continued to evolve after the mediatized events within less visible dynamics of contestation.

The objective of this article is to discuss particularly how this series of mobilizations embedded a relevant debate around the social judgment regarding journalistic practices and a consequential "desire of reform" towards an "ideal journalism", such

2 All translations from originals in Portuguese and French were made by the author. 
as described by Géraldine Muhlmann (2004). It will also discuss the participation of community and alternative media in the Journeys of June and its effects over the media sphere in general. Accordingly, it will bring up to discussion the assumption that this kind of media initiatives help, on a regular basis, to develop journalism and improve democracy.

Journalism and media can be placed among the main elements in the evolution of the Journeys of June, as a massive mobilization where networks and communities of knowledge $^{3}$ played an important role in the nature and form of engagements. First, the attempt of mass media to classify people in the streets as vandals and justify the violence of police against citizens participating and journalists covering the demonstrations can be considered as part of the turnover point that motivated thousands of people to take part of the movement. Secondly, as a consequence, a debate around the conditions and practices of journalism in the country was established, even leading to some particular demonstrations addressing specific media companies, such as Globo ${ }^{4}$.

It is debate that concerns not only traditional journalism but the media sphere as a whole. During the Journeys of June, the use of alternative platforms of communication, especially social networks, was central for denunciating the violence and reveal the bias of mass media covering. Some media activists evaluate that they were able to set mass media, which was forced to change the speech from the condemnation to the support of demonstrations. These alternative media were very important as well in the call for participation as in the broadcasting of information directly from the streets, as it was observed in most of the massive protests post-2010 all over the world (Gerbaudo, 2012).

In a later research, I have observed a strong influence of the media practices applied during the Journeys of June in the evolution of a "media logic" (Lundby, 2009) that has been transforming community and alternative media all over Brazil. The

3 Although I am not here directly applying the notion of "emergent local knowledge communities" developed by Jorge González, this idea of networks and communities of knowledge is inspired by his concept of "cibercultur@” as “an open and adaptable process that generates a range of emergent answers" (González, 2014, p. 38). My understanding here refers to dynamics where people engage in collective action based on or moved by the exchange of knowledge, meaning production, consumption, re-production and diffusion of information that makes sense within collective experiences.

4 According to data organized by the Media Ownership Monitor, Globo Corporation is the world's second largest TV network, only behind North-american ABC. The group holds five terrestrial televison channels, four newspapers, 14 magazines, 16 websites, three radio networks along with other 50 affiliates, and Globosat, the group's branch in cable TV. (Reporters Without Borders / Intervozes, 2017) 
appropriation of media platforms was consolidated as a way to develop and make visible alternative and competitive narratives, guiding online and offline strategies (Suzina, 2018). This article concentrates in the dynamics during the mobilizations of 2013, taking them as a microcosm that is highly representative of this emergent mediatized culture as well as of the strongly asymmetrical nature of the Brazilian media sphere (Suzina, 2016).

The article is organized in four main sections. The first one proposes a discussion about journalism and democracy. It focuses on media framing processes and the way community and alternative media can interfere in those dynamics. The second section presents the methodology and cases approached. The third section brings up the results of an analysis of the front pages of Folha de S. Paulo, a national Brazilian mainstream newspaper, during the month of mobilizations, as well as a first approach to the perspective of social actors. Finally, there is a section of debate, where I propose a discussion about the role of media in a democratic society.

\section{ABOUT JOURNALISM AND DEMOCRACY}

The reflections and debates around journalism and democracy date long back in time and cover a variety of perspectives and approaches (Muhlmann, 2004; Müller, 2014). In this article, the discussion takes two of many possible axes. They are both related to social movements and marginalized communities. The first considers how these actors are framed by mainstream media. The second regards how they build their own media in reaction to these framings. This initial section brings up some reflections about these issues, illustrating the debate with the case of the Journeys of June, the national mobilizations that took place in 2013 in Brazil.

\section{Framing contest and marginalized actors}

The studies about media framing justify its importance by defining it as a process with significant effects over the construction of social issues. The power and the polemics around framing are related to its dynamics of selecting aspects of a reality to promote certain definitions and interpretations (Entman, 1993; McQuail, 1994; Nelson, Clawson, \& Oxley, 1997). It is important to highlight that the effects of media framing are commonly studied separately for long term effects (how gender or race, for instance, are depicted by media) and for immediate effects (how one mobiliza- 
tion was covered, for example). In this article, the objective is to suggest that both processes follow the same pattern and that the alternative covering of Journeys of June triggered a debate around this connection between long and short term effects.

In this sense, the most useful definitions of framing are those that relate it to processes of visibility and meaning-making. Stephen Reese talks about framing as "organizing principles" symbolically working to "meaningfully structure the social world" (Reese, 2001, p. 11). They would contribute to what Boaventura de Sousa Santos (2007) describe as the "abyssal lines", i.e., the social constructions that build intentionally a frontier between the existent and the nonexistent.

Particularly, a great number of studies have revealed how contestant and marginalized actors are placed in two problematic positions in relation to this frontier. Either they are in the side of nonexistent, being completely neglected by the media covering, or they exist, although marked by negative associations such as crime and disorder (Miguel, Biroli, \& Duailibe, 2013; Rovira, 2013; Suzina \& Pleyers, 2016). Todd Gitlin argues that the power of media professionals consists of attributing meaning to social movements actions without no voice back about the frames produced (Gitlin, 1980).

For Venício A. de Lima, during the Journeys of June, the Brazilian "old media" have showed the same behavior as always. He says that "the absence of connection (in other words, the disconnection of the old media from the most majority of the Brazilian population) has been diagnosed a long time ago" (Lima, 2013, p. 93). For him, at least one of the reasons for the massive demonstrations was a combination of the sense of lack of political representation in the Parliament with - and derived from - the lack of representation in the public debate. He says that "the large diversity of opinions present in the society does not find channels for public expression neither has the means for making itself represented in the public debate that establishes the public opinion" (Lima, 2013, p. 93).

Jürgen Habermas proposes that "we understand the act of speech when we know what makes it acceptable" (Habermas, 2012, p. 515). Contradictory situations, such as the media covering during the Journeys of June and others denounced by media activists, may trigger a spirit of doubt or even rejection regarding the legitimacy of speech acts. They question social arrangements (Honneth, 1995) through the discussion about who is legitimate to describe the social world and define its main issues.

Changes in the media sphere, meaning mainly the access for new actors would then touch the functions of mutual understanding (Habermas, 2012). This context approaches the function of production and innovation of interpersonal relations re- 
garding mainstream media as a discursive actor whose legitimacy is challenged. It grabs the function of representation or presupposition of states and events while new speakers become able to present their worldviews. And finally, it seizes the function of manifestation of experiences bringing to light practices that have been ignored or stereotyped until then.

Habermas himself, as well as other authors, such as Dominique Wolton, problematize the enlargement of access to the public debate, arguing that the increasing number of players does not necessarily correspond to more deliberation (Habermas, 2006) or connection (Wolton, 2005). As suggested by Luis Felipe Miguel (2014), however, I take the dissonance produced by the inclusion of new actors in the media sphere cannot as a first step of change, considering its disruptive potential.

\section{Community and alternative media as legitimate actors}

In a country as large as Brazil, it might be utopian to speak about a medium that could cover the entire diversity of social and cultural manifestations. So, in one hand, it would be possible to accept the structural limitation of diversity and a consequent "structural homogeneity" (Muhlmann, 2004, pp. 92-93) in the constitution of the public sphere. This reflection moves the problem of framing to the issue of the hegemony behind the homogeneity, which would be inhibiting the incessant collective reconstruction of the common. Géraldine Muhlmann criticizes the naïve Kantian perspective, in which this reconstruction would be naturally nourished by an "ideal journalism" that makes room for the plurality of views (Muhlmann, 2004, p. 92). In this sense, the "structural homogeneity" can be a condition but still constitute a public arena, meaning an intense dynamic of argumentation, as conceived by Daniel Cefaï (1996).

Accordingly, in the other hand, it would also be possible to approach the large media system. In this case, the response would be closer to what proposes Michel Foucault (1994), i.e., "the problem is to multiply the channels, the bridges, the ways of information, the television and radio networks, the newspapers" (as cited in Muhlmann, 2004, p. 85). That is where community and alternative media may play an important role. They can bring up social actors and struggles from the level of "prepolitical" (Muhlmann, 2004, p. 71) to the one where the action is turned into a rational image and can influence the organization of the society. In such a perspective, the diversity takes the form of an information ecology (Nardi \& O'Day, 2000; Treré, 2011), composed by a variety of media outlets, that propose different facts but also different narratives about each fact. 
The use of media has been part of the strategies of social movements and activists for a long time all over the world. Described under several different concepts such as popular communication, participatory communication, citizen's media or communication for social change among others ${ }^{5}$, for the most part, they configure communication processes "which allow people themselves to define who they are, what they want and need, and how they will work together to improve their lives" (Gumucio-Dagron \& Tufte, 2006, p. xiv). In Brazil, struggles and actions related to the appropriation of media have started in the 1960's with a strong participation of the civil society, both in the development of initiatives as in the debate around public policies for the field of communication and media (Lima, 2006).

In Latin America, long term initiatives of "popular communication" refer to the culture of the so-called popular classes - which includes indigenous people, those living in peripheries and suburbs, campesinos and all groups that are excluded from the dominant elite culture - who use media outlets to produce or highlight a narrative opposed to a dominant one (González, 1990; Peruzzo, 2008). It also and mainly refers to practices searching for the emancipation and the improvement of life conditions of these groups (Festa, 1984; Gimenez, 1984; Otre, 2015).

For Cicilia Peruzzo, the active participation of citizens in the management and delivery of contents leads to the development of processes educomunicativos, meaning the appropriation of communication skills and techniques in order to improve individual and collective participation, and hence the exercise of democracy and citizenship (Peruzzo, 2006). Taking part in communication experiences may thus contribute to bring up the daily lives of citizens into the public sphere. This exercise helps to establish a connection between everyday experience and the more global context of political debates. Charged with this values, the public sphere is no longer a place for experts and democracy is no longer something reserved for politicians and intellectuals to become a topic in real life actions.

Peruzzo (2006) advocates that popular and alternative media carry on the right to communication, which includes access to information itself as well as the opportunity to participate in its production and distribution. She explains that this kind of

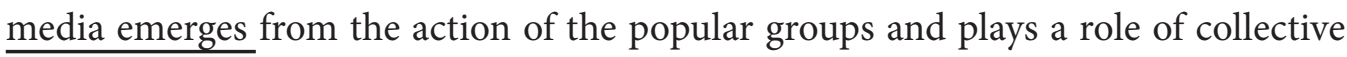
5 These different concepts have been used by authors around the world following different approaches and according to different contexts of action. For more information about each of them, including references about authors dealing with these different approaches, I recommend the book "Communication for Social Change. Anthology: Historical and Contemporary Readings", edited by Alfonso Gumucio-Dagron and Thomas Tufte (2006). 
mobilization. It also comes from the people - with their participation or in relation to their aspirations - and/or is directed to the people (Peruzzo, 1998).

The emergence of digital culture introduces new opportunities in this field, mainly easing the opportunity of reaching new audiences. For Manuel Castells, "the advent of digital communication, and the associated changes in organization and culture, have deeply modified the ways in which power relationships operate" (Castells, 2013, p. xix). This author enhances the potential of the internet to increase the autonomy of the communicating process, opening opportunities for individuals to produce selfmassive information, meaning that a message issued by only one person or group can reach massive audiences without or at least with less interference from owners and regulators of the communicative infrastructure.

Much of studies on activism and social movements in relation to the internet have focused on the protest and large mobilizations (Rodríguez, Ferron, \& Shamas, 2014). However, activism is not limited to the protest and the Journeys of June make a good case in this sense. The mobilizations themselves exposed the media framing as that process of meaning making described above together with an emergent capacity of reaction coming from the civil society. At the same time, as long as the protests included claims regarding the democratization of media, they led the debate to a general reflection about the configuration of the whole media system.

\section{METHODOLOGY}

This article analyses the debate about media and democracy that came up in Brazilian streets during the mobilizations in June of 2013. The reflection is based on a two-step approach. The first observes the evolution of mainstream media covering during the protests, assuming that it played a role in the evolution of the protests themselves. The second refers to the inclusion of claims related to media in the demonstrations and its roots in the struggles for media democratization in the country.

The first step consisted of the analysis of the front pages of the newspaper Folha de S. Paulo, from $7^{\text {th }}$ to $30^{\text {th }}$ of June 2013. Titles, texts and images figuring only on the front page were taken into account, considering two main reasons: the dominant communicative power of front pages comparing to articles; and the high exposure of front pages that reaches regular readers but also a larger audience of those just getting the frontlines (LEMEP, 2016). Folha de S. Paulo was picked to illustrate what has 
been said about the demonstrations because of its representativeness in the Brazilian media sphere. It is the daily newspaper of largest paid circulation in Brazil (Reporters Without Borders / Intervozes, 2017), reaching the average of 300.000 copies daily (Grupo Folha, n.d.). Additionally, as the events that are considered as the catalyzers of the national mobilizations took place in the city of São Paulo, this newspaper could provide material for analysis covering the whole period of peak of protests.

It is relevant to highlight that the goal of this article is not to provide an extensive analysis of valence frames, although it follows the main elements of this method. Mainly, it observes how Folha de S. Paulo "select[ed] some aspects of a perceived reality and make[made] them more salient in a communicating context", which configures a classic framing mechanism (Entman, 1993, p. 52). The elements observed on the front pages were: main headlines, pictures, short texts introducing articles, titles introducing articles and editorials. In all of them, the first step of the analysis consisted of identifying: the mention (or not) to the mobilizations, the size and the position of the headline and of the introductory texts, the use (or not) of images, the size and the position of images, and the words chosen to describe the events.

All references to the protests were, then, classified according to their tone, that could be neutral, negative or positive. I considered neutral elements that showed the information without explicitly classifying it as positive or negative, meaning that the description of protesters did not depict them neither as aggressive or dangerous nor as honorable citizens. Negative elements highlighted aspects that connected the demonstrations to violence, destruction and social disorder - they suggest that the repression is justified. Positive elements depicted participants as citizens, social actors influencing a political decision, and also as victims of the violence of the police - they suggest that participants have the right to protest and/or even are contributing to democracy. The objective of this level of analysis was, then, to offer some evidence of the evolution of editorial choices that legitimated either the repression of the State or the social mobilization.

The complementary step constituted a dialogue between the observation of the mainstream media covering and the perspective of actors enrolled in community and alternative media practices, some of them directly involved in the Journeys of June. The approach to the actors was done through semi-structured personal interviews conducted during the months of October and November of 2013 with Brazilian journalists and media activists from Mídia Ninja (multimedia, digital, national range; 1 
person interviewed), Coletivo Nigéria (audiovisual, digital, national range; 2 people interviewed), Jornal do MST (newspaper, national range; 1 person interviewed), Rede de Notícias da Amazônia (network of local radios, Amazon region; 1 person interviewed), Rádio Ibiapina (community radio, local range, Northeast region, 3 people interviewed), Rádio Fundação Casa Grande (community radio, local range, Northeast region; 2 people interviewed) and Fala, Mãe Luiza (community newspaper, local range, Northeast region, 1 person interviewed).

All interviews were developed personally and most of them took place during field observations in the places where the media practices are usually developed the exceptions were the Rede de Notícias da Amazônia and the newspaper Fala, Mãe Luiza, whose communicators were interviewed during a meeting of popular communicators before each respective field immersion that took place afterward. The interviewees were all communicators leading media practices in their organizations.

The objective was double. On the one hand, to confront the "particular problem definition, causal interpretation, moral evaluation, and/or treatment recommendation" (Entman, 1993, p. 52) applied by Folha de S. Paulo during the manifestations with the perspective of the actors. On the other hand, the idea was to situate this debate in the larger framework of media and democracy, including a discussion about the role of community and alternative media.

\section{THE VOICES IN THE MEDIA AND THE VOICES OF THE ACTORS}

This section is divided into two parts. The first presents the results of the analysis of the front pages of Folha de S. Paulo. This analysis is also organized in two parts, to better explore the positive and negative editorial approaches observed in the covering. The second part exposes some of the ideas identified during the interviews with the actors.

\section{The Journeys of June in the front page of Folha de S. Paulo}

Between the $7^{\text {th }}$ and the $30^{\text {th }}$ of June 2013, the Journeys of June were the subject or were mentioned in 128 pieces in the front pages of the newspaper Folha de S. Paulo. The demonstrations were the subject of the main headline 13 times and 34 images of the acts were exposed in the front pages during the period. The evolution of the covering can be observed in the Figure 1, that shows also that it begun with a negative trend, 
made a drastic turning point around the $13^{\text {th }}$ of June, when the numbers of pieces mentioning the demonstrations increased ${ }^{7}$, to end with a neutral-positive trend.

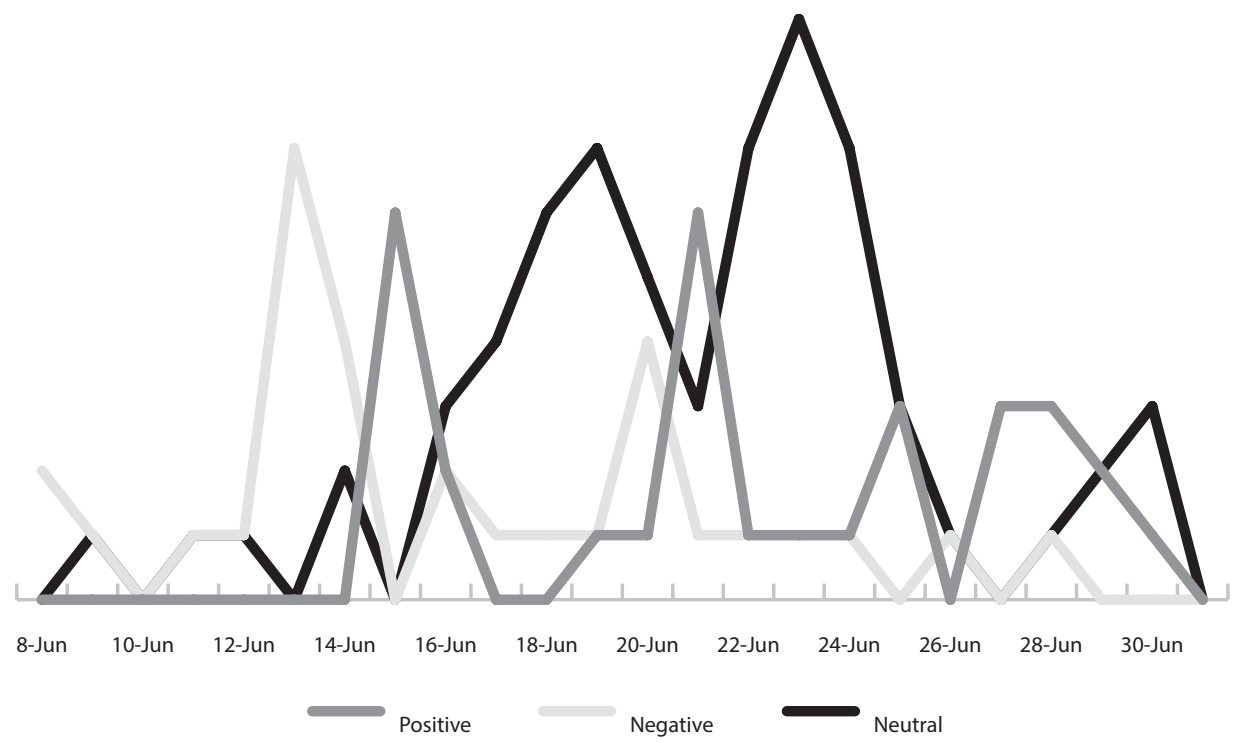

Figure 1. Evolution of the covering of Journeys of June in the front pages of Folha de S. Paulo

Accordingly, the analysis of the front pages of the newspaper Folha de S. Paulo was divided into two groups, that correspond to two opposite approaches to the facts. The first one shows a covering close to the criminalization of social movements. The other corresponds to a change on editorial choices that depict the mobilizations inside the framework of citizenship. As we will see, this evolution is close to what has been observed as an impact of the use of digital media in the context of social mobilizations in other regions of the world.

\section{The discourse of criminalization}

Manipulation, over simplification, sensationalism, partiality, artificiality. These are some of the critics directed to journalism, and mainly to mass media, all over the world. As exposed by Muhlmann:

7 In the 23th of June, Folha de S.Paulo printed a special issue devoted to the protests, featuring several introductory texts on the front page. These introductory texts were counted and classified for this article, but the special issue itself did not. 


\section{Media practices in the Brazilian mobilizations of 2013}

Journalists are criticized for imposing points of view biased, in the service of the powerful, distorted from the exchange of opinions and perspectives that would occur naturally in the public space if this space was not precisely in the hands of media. (Muhlmann, 2004, p. 25)

In June of 2013, the mass media in Brazil left room for hardening these ideas. The disputes around the construction of a narrative and of the meaning of the series of massive protests exposed the asymmetrical relationships that characterize Brazilian democracy (Suzina, 2016, 2018). The period can be described as a microcosm of a situation where deep inequalities in resources and recognition turn into power asymmetries, establishing what voices are allowed not just to be included but to interfere in the public debate.

During around three weeks, more than three million people went to the streets claiming for changes in several fields of public services (Secco, 2013). The demonstrations were originally called by the Movimento Passe Livre (MPL), a social movement who challenges the situation of the public transport through local and horizontal mobilizations all over the country. They started in the city of São Paulo, in reaction to the increment of 20 cents in the price of the transport ticket and followed the same strategy of mobilization applied by the movement in precedent opportunities, i.e., mainly young people sum up to demonstrations blocking streets and to popular and open assemblies, where anyone can take the word for deciding the ways and the form of the actions (Passe Livre SP, 2013). The movement fits largely the model of action that characterizes the "alter-activism" (Pleyers, 2010), dialoguing in approach with several mobilizations that spread after 2010 in different regions of the world, such as Occupy Wall Street, in the United States, Los Indignados, in Spain, Nuit Debut, in France, or Gezi Park, in Turkey.

The first reaction of mass media to the Brazilian protests in early June was to condemn the demonstrations and characterize their participants as vandals, as it was possible to see in the front page of the newspaper Folha de S. Paulo (see Figure 1 and Table 1). 
Table 1

Front page of Folha de S. Paulo in the beginning of the Journeys of June

\begin{tabular}{cll}
\hline Date & \multicolumn{1}{c}{ Title } & \multicolumn{1}{c}{ Dimension } \\
\hline June, 7th & $\begin{array}{l}\text { Vandalism characterizes act for } \\
\text { cheaper transport in São Paulo }\end{array}$ & $\begin{array}{l}\text { Small note in the top of the page, with big } \\
\text { picture of streets on fire }\end{array}$ \\
June, 8th & $\begin{array}{l}\text { Protesters cause fear, block highway } \\
\text { and spray messages on buses }\end{array}$ & $\begin{array}{l}\text { Small note in the down side of the page, } \\
\text { with a big picture of people running in the } \\
\text { streets }\end{array}$ \\
June, 12th & $\begin{array}{l}\text { Against the price of the ticket, protest- } \\
\text { ers vandalize the center and the Pau- } \\
\text { lista Avenue }\end{array}$ & $\begin{array}{l}2 / 3 \text { of the page, with three pictures of } \\
\text { streets and buses on fire, and the police at- } \\
\text { tacking the protesters }\end{array}$ \\
June, 13th & $\begin{array}{l}\text { Government says that it will take } \\
\text { harder against vandalism }\end{array}$ & $\begin{array}{l}1 / 3 \text { of the page with a big central picture } \\
\text { of an injured policeman arresting his ag- } \\
\text { gressor and defending himself with his } \\
\text { gun pointed to the crowd (we don't see the } \\
\text { crowd, that is suggested by the text) }\end{array}$
\end{tabular}

Note. Source: Author with information from Acervo Folha (Folha de S. Paulo, 2013)

As a telling anecdote, in June $12^{\text {th }}$, there is a specially interesting element regarding the editorial decisions of Folha de S. Paulo. While protesters were associated to vandalism in the streets of São Paulo, the newspaper published a small note informing that "Turkish police represses activists in a square of Istanbul", referring to a same kind of mobilization in the Gezi Park that became internationally recognized as well (Pleyers, 2018).

The fourth demonstration was strongly repressed by the police and, while the mass media kept affirming that the violence was a response against the vandalism of protesters, amateur videos and records from media activists and journalists started to show a different story on the Internet. They revealed scenes where the police attacked people singing or exhibiting posters with political messages. Media actors such as Mídia Ninja and Coletivo Nigéria started to become legitimate as a source of information coming directly from the streets (see next section).

In the $13^{\text {th }}$ of June, there is a turning point in the covering and the negative trend diminished. Pieces reporting acts of violence were still present in the front pages until the end of the month, but they were not prevalent anymore. 


\section{The emergence of a new perspective}

As long as thousands of people decided to join the demonstrations - or organize new ones in their cities all over the country - and diversified information was circulating around, it was possible to see an evolution in the headlines on Folha de S. Paulo (Table 2). In the front page of this newspaper, vandals became protesters who were playing acts, even if when there were still mentions to situations of vandalism.

Table 2

Front pages of Folha de S. Paulo in the evolution of the Journeys of June

Date Title Dimension

June, 14th Police react with violence to a pro- $3 / 4$ of the page with a big picture in the top test and São Paulo lives a night of showing a policeman attacking a woman chaos plus another small picture of a journalist who was shot in the eye with a rubber bullet

June, 17th The government of São Paulo asks $2 / 3$ of page with a picture showing conand will have a meeting with protest- frontation between protesters and the poers today lice in Rio de Janeiro, with reference to a football match of the Confederations Cup

June, 18th Thousands go to the streets 'against everything'; groups reach palaces

Whole page with a big picture showing the shadow of protesters in the National Congress, in Brasília, a small picture of a crowd in the center of São Paulo, and a series of smaller images showing different political complains expressed by protesters

June, 19th Act in São Paulo includes attack to the City Hall, sacking and vandalism; police slow to react

Whole page with a big picture of the municipal guard defending the building, and smaller images of a TV station truck on fire, a protester walking down with a stolen TV, and a crowd in the center of São Paulo

June, 20th Street protests put fares down Whole page with a big picture of a crowd showing posters with complains, and a smaller image of another crowd watching the announcement of the reduction of the fares

Note. Source: Author with information from Acervo Folha (Folha de S. Paulo, 2013) 
There are several important elements to take into account in the change of tone in the headlines of Folha de S. Paulo. It meant actually the emergence of positive approaches towards the demonstrations, such as those where protesters were depicted as active citizens searching for their rights and the State begun to show up as repressive or looking for dialogue with the citizens. But it corresponds mainly to a more balanced covering, with a high number of neutral pieces disposed together with positive and negative approaches (see Figure 1). There was place to pieces reporting profile and motivations of protesters, negotiations between actors involved in the organization of the acts as well as the evolution of popular demands in the political agenda. Headlines called to articles developing sociological and historical hypotheses about the mobilizations and the role of the police. But there was also room for information regarding acts of vandalism, robbery and other disorders.

It is equally relevant to highlight that the end of the covering, meaning the last week of analysis, frequently presented the protests as a background for approaching political issues, such as positions of and measures taken by the Executive and Legislative powers regarding claims expressed in the streets. In most of these cases, the demonstrations were just mentioned as the reason or the motive behind a debate or an action. This aspect of the change deserves further analysis regarding the editorial tone applied to report the acts of president Dilma Roussef, who started to appear as the main political actor to blame for every problem displayed in citizens' claims. The observations of the present sample suggest a link to the editorial approach that was consolidated in the following months, introducing the electoral (2014) and the impeachment (2016) processes.

\section{The perspective of the actors}

As already mentioned, the turning point in the mainstream covering came at the same time as alternative narratives started to be intensively reproduced on the Internet. This is another feature shared between the Brazilian demonstrations and most of massive mobilizations post-2010 in other countries, where digital platforms of communication played a central role (Gerbaudo, 2012; Pleyers, 2018). In Brazil, among many groups and citizens providing information from the streets, some got more notorious. It is the case of Mídia Ninja and Coletivo Nigéria.

For some media activists, such as Rafael, from Mídia Ninja, the change in the discourse of mainstream media was considered as a kind of victory of this confrontation 


\section{Media practices in the Brazilian mobilizations of 2013}

of perspectives. He considered that their production has set mass media and transformed narratives during the Journeys of June:

The person who has figured in the cover of Revista $\mathrm{Veja}^{8}$ was someone identified by our covering during the demonstrations in Rio; and during three days the Jornal Nacional ${ }^{9}$ [Globo] had to use our images in the case of Bruno Teles ${ }^{10}$, because their team was not able to get the story.

The name NINJA stands for Narrativas Independentes, Jornalismo e Ação and the initiative consists of a network of mainly young people spread all over the country, who produce and broadcast information through a webpage on Facebook and other digital platforms. During the demonstrations, they went to the streets with cameras and smartphones recording and broadcasting everything that crossed their path they frequently used live and long transmissions. The number of views and "likes" on their page jumped to thousands and their content started to be reproduced all over.

For Rafael, the legitimacy of their alternative covering came from its capillarity and independence, as he explained:

In the last two or three years, we have been debating and building what would be the foundations of a network connecting people that were already doing live photography, using social media all over Brazil (...) When June comes, we were the most prepared to do this B-side covering of the streets of June, we were in the streets all over the country, with an autonomous self-managed and self-financed system. We did not have a skeleton in the closet and, so, we could speak about everything that was happening.

Coletivo Nigéria is an entrepreneurship of four young journalists, located in Fortaleza, Ceará, in the Northeast region. It is a project that mixes video production for social movements and NGOs with initiatives of media activism. They also went out to the streets to follow up the demonstrations and get alternative information in relation to what mainstream media were showing. For Yargo, one of the media activists of Coletivo Nigéria, June was the moment of an "explosion". He explained that they were

8 Another mainstream media outlet, Revista Veja is a weekly magazine with a very conservative editorial line. 9 Jornal Nacional is a daily TV news program, broadcasted by Globo TV on national range.

10 The case is related to the detention of the protester Bruno Teles, who was accused of carrying on explosive devices and detained even if there was divergent information among different police records. 
already broadcasting information about the impacts of the World Cup before, but after the Journeys, the number of likes on their Facebook page increased "from 150 to more than 3.000". For him, "there was evidence of a need of contra-hegemonic information, alternative information, which ended up by making our work better known".

Differently from Mídia Ninja, they did not transmit live but used to work in careful editions before publishing their material. One of their most popular pieces, by the moment we met, was the documentary "Com Vandalismo" [With vandalism] (Coletivo Nigéria, 2013), whose objective was to establish a debate around the discourse of vandalism in relation to what actually happened during the demonstrations and its motivations. Only until December 2013, this video had reached more than 150.000 views on Youtube.

Between the actors interviewed, including those involved in the Journeys of June and others more related to longstanding traditional popular media, there are some common elements. The first one is that the need of being represented is related to the capacity of making their actions a valid option for them and maybe for the whole society. Being represented is interpreted by these actors as being recognized as citizens. The public space would be, then, the space of citizenship, meaning mainly being seen as who they are - and not as a stereotype that fits a homogeneous definition -, and maybe being taken as reference for others as a result of this exposition.

The change in the editorial approach during the Journeys of June is not a particular case of Brazilian protests. Several authors have tracked the influence of digital media over mainstream covering during collective actions all over the world, such as the Arab Spring, the Occupy movement, the mobilizations for public education in Chile, among others (Navarro, 2016; Ponce Lara \& Miranda, 2016; Lecomte, 2013/5; Galindo, 2016). All these cases share a similar dynamic with three particular moments: first, the collective action suffers from a situation of invisibility or bad covering; then, there is a massive exposition of alternative information on the Internet and social networks; and finally, there is a transformation in the mainstream narrative. The perspective renews the hopes of media activists, as we have seen above, but the regular relationship between mainstream media and social movements seems to be still fragile.

These actors seem to clearly recognize the limits of the media sphere, but they are still faithful in their media action as an instrument to leave the private space and take part in the public one, confronting the mass of society. In this sense, Rafael gave an interesting statement saying that he does not conceive Mídia Ninja as the voice of the 
social movements. "These groups already have a voice and what we want is to make it louder, to make it visible", he declared. They would embody a character close to what Foucault calls as the "diagnosticien du présent" (Foucault, 1994), who is the one who refocus the gaze and makes visible what is visible but not yet seen (as cited in Muhlmann, 2004, p. 86).

\section{THE IDEAL OF AN IDEAL JOURNALISM}

In the $5^{\text {th }}$ of August, one of the most traditional debate programs of the Brazilian television, called Roda Viva, brought two of the leaders of Midia Ninja to the discussion and the character of their work was one of the central issues. In this occasion, Bruno Torturra, journalist and one of the founders of the initiative affirmed that journalism is what it is (TV Cultura, 2013). Later, during an interview for this research, Rafael said that it is also journalism. No matter what the answer finally is, what this debate represent is that there is a question regarding the limitedness of what Lima (2013) calls "old media" as well as about what is the possible reform of journalism and what is the room for new practices in the media sphere.

All journalists and media activists consulted are pretty close to the enthusiastic perspective of criticizing the media. Even if they recognize the effects of the monopoly of media in Brazil and the precariousness of the field of journalism, they are ready to press up for transformations and to develop alternatives for improving the general debate in the public sphere. As suggested by Muhlmann, they accept that the public sphere is a place affected by dominations, where the plurality is always imperfect (Muhlmann, 2004).

There is a trend of getting close to the Kantian ideal of an autonomous thinking as a result of the freedom of expression. This idea is frequently present in the discourses of the young communicators leading very innovative initiatives such as Mídia Ninja and Coletivo Nigéria. For instance, Rafael declared being convinced that if people get access to different views of an issue, each citizen will be able to decide what to think. That's why he defines the editorial line of Mídia Ninja as "multipartial". It means showing the different perspectives, even if he has declared that in their "multipartiality", there is one declared partiality of making visible the word of social movements

and groups that are regularly neglected by mass media. The main goal, for him, is to establish the conflict that may lead to better decisions: 
We have been broadcasting the demonstrations and for every link, for example, the pictures that we post, if there will be an act today, we post a picture with 8-10 links of streaming. Each person chose his/her preferred storyteller, the worldview that will be there, what each one will be showing. It is in this sense that we say that you chose what you want to see. You sum up them, you get your conclusions. We won't give it ready, in a certain way. We have no problem of diffusing a specific idea, but we believe that the construction will be upon it, upon this diversity.

Yargo and his partner Pedro, from Coletivo Nigéria, also believe in the competence of the public for identifying the contradictions when faced by a plurality of views. They think that time has arrived for rethinking the journalism as a whole and that this will include more space for investigative journalism and for other platforms for diffusing information, outside mass media. Both Mídia Ninja and Nigéria already try innovative languages and formats, mixing text, photography, audio and video resources. Rafael said that, after getting a bunch of information about an issue, Ninja's team concentrate themselves in the choice of the best package for achieving the maximum of audience.

Yargo and Pedro seem to be less worried about the number of people consuming their information. They agree that it is important to care about the audience but it is equally important to avoid being hostage of the public and, therefore, repeating the same mistakes of the mass media. Again, they highlight this idea of the importance of searching for answers outside mass media. They want to break the monopoly denounced by Lima, who says that

Even if they are 'connected' by these networks [social networks] and, then, even if they do not get their information, do not have their entertainment and do not express themselves (primary) by the old media, the youth who triggered the demonstrations still depend on them to achieve public visibility, i.e., to be included in the space that constitutes the public opinion. (Lima, 2013, p. 90)

\section{Generalization: the roots of the problem}

Most of the journalists and media activists interviewed goes in the same direction, criticizing mass media as a frequent obstacle for achieving the conditions for seeing and been seen. The tension between mainstream media and social movements, that 


\section{Media practices in the Brazilian mobilizations of 2013}

exploded during the Journeys of June, was depicted as a permanent condition by these actors. They talk about their mission as making visible people, situations and opinions that use to be inaccessible for the public eyes or represented as just a part of who they are and what they mean. The claims for a better journalism as well as the attacks against media companies (see below) during the demonstrations reveal a general discontent in relation to the asymmetrical condition of the Brazilian media sphere.

Some of these media activists fight for enlarging the debate in the society as a whole, some others work from particular groups or regions, such as Júnior, from the community newspaper Fala, Mãe Luiza, in the city of Natal, Rio Grande do Norte. The publication was created in 1989 to challenge the negative image diffused by mass media about the neighborhood - which name is Mãe Luiza. He explains that "through the community newspaper, the community can see itself out of the stereotypes and as part of the world".

Júnior advocates the importance of approaching the issues of the neighborhood from the perspective of its own dwellers, principle that is defended also by the team leading the Rede de Notícias da Amazônia (Network of News from Amazon), a network of local and catholic radios that share contents and produces regional programs about the reality of the Amazon Region. Rosa, a partner in the project, explains that the initiative was established in 2007 for "opposing the information coming from the South, that frequently focus on the disgraces of Amazon" and for "making the Amazon known by its people, for allowing Amazon to talk to the Amazon".

\section{The condemnable practice of journalism}

The bleak perspective for criticizing the journalism - critique sombre, as named by Muhlmann - is also present in the Brazilian debate. From this point of view, the democracy is a regime where the exchange of public opinions is affected by a strong homogeneity and the journalism reflects this domination (Muhlmann, 2004). During the Journeys of June, and especially in the protests that came later on, this critic was mainly focused in the monopoly of media ownership, an old complain of social movements and media activists.

The Intervozes Coletivo Brasil de Comunicação Social is an NGO that defends the right to communication as a way to free people from the hostage of media controlled by powerful actors. In a film called "Levante sua voz" [Raise your voice], they illustrate the control of the media sphere in Brazil by the confrontation of the number 
of 11 families who own most of the media in the country with the tens of thousands of applications for getting authorization for the establishment of a community radio (Ekman, 2009). The Media Ownership Monitor confirmed the high concentration of the Brazilian media sphere:

Despite the vast regional diversity in the country and the continental dimensions of its territory, the four main media groups concentrate an exorbitant national audience - over 70\% in the case of free-to-air television, the most popular media in the country. (Reporters Without Borders / Intervozes, 2017)

Data collected by Angelo Serpa illustrate the situation with the example of Salvador, in the state of Bahia. According to him, between 1999 and 2005, the national authority prevented 537 radio stations from start working in the city and only $31 \%$ of all requests made got a permission (Serpa, 2013). Despite some efforts from the governments of the Workers Party (2003-2016), the legal and structural framework of media operations in the country kept highly restrictive. For instance, in 2010 and 2011, around two radio stations operating without permission were closed every day all over the country (Paiva, Malerba, \& Custódio, 2013).

As Muhlmann suggests, the situation of the journalism tends to be connected to the situation of the democracy where it is developed. The inequality in the media sphere in Brazil seems to be very close to social and economic inequalities. Vilson Vieira Jr. established a relationship between poverty in different Brazilian regions and the concentration of media. He takes as reference a study of EPCOM, in 2006, that pointed out

A direct relationship between the economic strength of a region and the degree of concentration or plurality of the media. (...) The poorer is the region the largest is the level of media concentration, i.e., the lower is the number of actors owning media such as radio and television, considering that the Gross Domestic Product (GDP) is directly related to the number of broadcasters and private TV operators in the states. (Vieira Jr., 2007)

According to Intervozes, the result of this monopoly of property is a homogeneity of issues, sources of information, actors and approaches represented in the public debate. Most of the journalists and media activists interviewed mentioned this ho- 
mogeneity, meaning both the lack of representation of the Brazilian social diversity in the media as well as the trend of building stereotypes that create kind of categories of what exists.

The concentration of property also means that a lot of the content is produced or selected from urban centers, like São Paulo, Rio de Janeiro and Brasília, or the capitals of the states, leaving a small space for local facts and perspectives and a lot of room for homogeneity. It means establishing patterns that do not necessarily correspond to the complexity of the Brazilian society, in a straight connection to the complaint towards the disconnection between the media and the situation of the Brazilian population.

For instance, Júnior justified the community newspaper as a way to show people inside and outside the neighborhood that Mãe Luiza has more than drugs and violence issues. In Nova Olinda, a small city in the interior of Ceará, João Paulo said that taking part in the project of the Fundação Casa Grande community radio made it possible for him to discover that he must not leave the city to be a citizen. This radio was established about 20 years ago, as part of a large cultural project that offers to children activities related to music, theater, cinema and media, always focusing on improving the access to cultural goods as well as highlighting aspects of local and regional history and culture. According to João, everything that he heard before, in the mass media, led to believe that they were isolated and far from reaching anything good.

In a context of such inequalities, it's possible to assume that when social groups decide to fight against mass media, in fact, they are fighting against a model of society that uses the media to reproduce itself. They are fighting against a cultural unity that was built upon a false homogeneity and avoids conflict. Therefore, it takes the risk of building a "crowd" instead of a public (Muhlmann, 2004).

\section{The role of popular, community and alternative media}

It is important to observe how the Journeys of June constituted itself a space where so called vices of mass journalism were exposed as well as an event that related the discussion about the Brazilian democracy to the one regarding the journalistic practices. Venício A. de Lima says that, in Brazil, despite the development of information and communication technologies and the crescent use of digital media, the "old media", as he names the traditional mass media, still keep the monopoly of visibility, of "turning things public" (Lima, 2013), which the agenda setting celebrated by media activists can illustrate. 
Social movements need visibility in order to get support for their actions and themes. Media are, therefore, a constant concern, an agent that is approached in a strategy of sharing information and beliefs, but also faced with criticism because of editorial preferences that criminalize social action and reduce or hide relevant social issues (Rovira, 2013; Barker, 2008). What gets visible, what is turned public became part of the complains during the demonstrations all over the country - probably motivated by the biased covering of the demonstrations themselves. Protesters recorded situations where reporters of Rede Globo were harassed in many cities by small or large groups of people yelling at them phrases such as "the people is not fool, Globo get out". There were cases of attacks against vehicles of Globo and other TV networks and, in July, some smaller protests were organized in cities such as São Paulo, Rio de Janeiro and Brasília, taking media as their central issue.

For Muhlmann, the question about how media keep their role as a mediation between the individual and the community is the very question of democracy (Muhlmann, 2004). Most of the actors interviewed agree that mainstream media in Brazil is far from this role. They justify their engagement with media initiatives as a mechanism for confronting both stereotypes produced by mainstream media and for introducing new issues in the debate. For Igor, from the Movimento dos Trabalhadores Rurais Sem Terra (MST), considering the big structural changes proposed by society, the community and alternative media have a role of preparing militants and citizens to understand the challenges and take part in the decisions. He makes a straight connection between the power of media framing and the possibility of social change, attributing to popular media a central role for vocalizing alternative perspectives:

Before, the enemy of MST and of the agrarian reform was the farmer, with his hat, his boots dirty with mud, his belt and his employees, who protected his land, that he used for real estate speculation. (...) This farmer was frequently associated to the worst political methods, to authoritarianism. In the last period, what have we got? A process in which transnational companies, Monsanto, Bunge, Cargill, Syngenta, come to Brazil and get associated to capitalist farmers, establishing a new model of production in the agriculture, which is the agribusiness. (...) Then, the society, because of the power of agribusiness over media, with advertisings that created a perspective that the agribusiness is modern, that it produces, it exports, it supports the Brazilian economy; the society looks to agribusiness and say 'it is good'. Now those who are old-fashioned are the ones fighting for redistributing the land, those 


\section{Media practices in the Brazilian mobilizations of 2013}

who do not produce anything, because the media do not give any space for diffusing our production experiences.

Digital technologies come with another wave of hope in this sense (Cardon, 2010; Castells, 2012). Some of the media activists interviewed talk about a "revolution of the filters", referring to the possibility of broadcasting a message by oneself, without passing by any gatekeeper, as newsrooms journalists are regularly described in the literature for their power over the decision of what become news. Some mention the possibility of reaching people far away without needing to make important investments in broadcasting equipment (Gonçalves, 2013; Lara \& Gheller, 2013; Rosembach \& Zottis, 2013). For many, it represents an opportunity for passing along a message that otherwise would be confined into already engaged publics, as it was the case of the alternative media that flourished during the mobilizations of June 2013.

Community and alternative media keep a role of development and emancipation inside communities and groups, as presented above. It is important to consider, though, that, even if mainstream media still keep the place of central source of information, the introduction of digital technologies gives community and alternative media another condition. If the access to mass media is still problematic, digital media become mass media, as "a new space with a higher potential reach and the opportunity to broadcast unfiltered content” (Sartoretto, 2016, p. 49).

The journalists and media activists interviewed decided to intervene, putting pressure over mass journalism and developing practices to get other voices louder. In this path, they may be contributing to one of the requirements proposed by Muhlmann, that involves decentring, i.e., researching permanently the otherness (Muhlmann, 2004). The results seem to be very positive regarding the case of the Journeys of June. The challenge would be to keep and enlarge this effect to regular collective actions promoted by social movements.

\section{FINAL CONSIDERATIONS}

This article has showed the change in the narrative of a Brazilian mainstream newspaper regarding a massive series of social mobilizations during June of 2013. The analysis revealed two main moments of the covering. The first characterized by 
a negative approach, where protesters were depicted as vandals and the repression of police, justified. The second moment brought up a mix of predominantly neutral and positive pieces, where the mobilizations were reported with more aspects and protesters started to figure as citizens searching for their rights.

The actions of alternative media, especially those structured upon digital technologies, can be depicted as a major element in this evolution, following an international trend in the context of social protest. They provided alternative perspectives and supported a popular engagement. At the same time, these dynamics triggered a reflection among the protesters themselves regarding the central role of media in the organization of society and, consequently, about the democratization of media. Actors already involved in community and media practices agreed with new media activists about the importance of improving actions in this field.

The Journeys of June opened a debate, or at least a conversation, around the role and the practices of journalism in particular, and media in general, in the Brazilian society. The mass media behavior regarding the demonstrations served as a confirmation for those who were already mobilized around the right to communication issue and invited other actors to take part in the discussion, especially the youth, who was directly involved in the events ${ }^{11}$ and felt betrayed for what was being showed by media.

And if the Journeys of June have triggered this debate, they have done it by highlighting new narratives and actors. Considering the size and the social and cultural diversity of a country like Brazil, we may be focusing a reform that does not touch mass media exclusively, but that is rescuing the role of local, regional, community and alternative media. They could be better considered in this tension of permanently reconstructing a common and feeding the conflict necessary to the democracy.

In this process, we could agree with Muhlmann that visibility is a main issue, but we should also take into consideration the new context where the digital technologies can play a role both as a platform for legitimating other actors as sources of information - and maybe as a complement for the traditional journalism - and as an actor that can influence the practices of the old media as well. Taking the journalism as a space of power and knowledge, with the author, we assume that its limits - and con-

11 "According to Folha de S. Paulo, 84\% of the protesters from São Paulo in 17 of June did not have preference to any political party, for $71 \%$ this was the first time they took part of a protest and $53 \%$ were under 25 years old." (Secco, 2013, p. 71) 
sequently those of the public sphere - can be treated, and maybe restored, by more journalism, more perspectives and more curiosity, presuming that community and alternative media play an important role in this process.

\section{REFERENCES}

Barker, M. (2008, April 22). Mass media and social movements. Retrieved from http:// www.globalresearch.ca/mass-media-and-social-movements/8761

Bringel, B., \& Pleyers, G. (2015). Les mobilisations de 2013 au Brésil : vers une reconfiguration de la contestation. Brésil(s). Sciences humaines et sociales, 7(mai), 7-18.

Cardon, D. (2010). La démocratie Internet. Paris: Seuil.

Castells, M. (2012). Networks of outrage and hope. Social movements in the Internet age. Cambridge: Polity.

Castells, M. (2013). Communication Power. United Kingdom: Oxford University Press.

Cefaï, D. (1996). La construction des problèmes publics. Définitions de situations dans des arènes publiques. Réseaux, 14(75), 43-66.

Coletivo Nigéria. (2013, July 26). Nigéria Audiovisual. Retrieved November 03, 2013, from Youtube.com: http://www.youtube.com/watch?v=KktR7Xvo09s

Ekman, P. (Director). (2009). Levante sua voz [Motion Picture].

Entman, R. (1993). Framing: Toward Clarification of a Fractured Paradigm. Journal of Communication, 43(4), 51-58.

Festa, R. (1984). Comunicação popular e alternativa: a realidade e as utopias. Dissertação (Mestrado em Comunicação Social), 290. São Bernardo do Campo: Instituto Metodista de Ensino Superior. 
Folha de S.Paulo, J. (2013, June). Folha.com. Retrieved January 07, 2014, from Acervo Folha: http://acervo.folha.com.br/fsp/2013/06/

Foucault, M. (1994). Dits et Écrits 1954-1988 (Vol. III). (D. Defert, \& F. Ewald, Eds.) Paris: Gallimard.

Foucault, M. (1994). Le philosophe masqué. In M. Foucault, D. Defert, \& F. Ewald (Eds.), Dits et Écrits 1954-1988 (Vol. IV, pp. 104-110). Paris: Gallimard.

Galindo, L. (2016). La red como cronotopo: Internet y prácticas políticas en el Movimiento Estudiantil Colombiano Mane y Occupy São Paulo. Observatorio.

Gerbaudo, P. (2012). Tweets and the streets. London: Pluto.

Gimenez, G. (1984). Notas para uma teoría de la comunicación popular. In Que es la comunicación popular y alternativa?: Dos documentos para discusión (2nd ed., Vol. 1). ECO Servicio de documentación: comunicación y solidariedad.

Gitlin, T. (1980). The whole world is watching: Mass media in the making \& unmaking of the new left. Los Angeles: University of California Press.

Gonçalves, C. V. (2013). Em Itapipoca "Web Rádio São Francisco.com” comunica, forma e divulga. $8^{\circ}$ Mutirão Brasileiro de Comunicação. Natal (RN).

González, J. (2014). Researching and Developing Cybercultur@: Emerging Local Knowledge Communities in Latin America. In T. Askanius, \& L. Stubbe Ostergaard, Reclaiming the Public Sphere: Communication, Power and Social Change (pp. 26-46). Basingstike: Palgrave Macmillan.

González, J. A. (1990). Sociología de las culturas subalternas. Mexico: UABC.

Grupo Folha. (n.d.). Conheça a Folha de S.Paulo. Retrieved May 28, 2014, from Folha de S. Paulo: http://www1.folha.uol.com.br/institucional/conheca a folha.shtml

Gumucio-Dagron, A., \& Tufte, T. (2006). Communication for Social Change. Anthology: historical and contemporary readings. New Jersey, USA: Communication for Social Change Consortium.

Habermas, J. (2006). Political Communication in Media Society: Does Democracy Still Enjoy an Epistemic Dimension? The Impact of Normative Theory on Empirical Research. Communication Theory, 16, 411-426. 


\section{Media practices in the Brazilian mobilizations of 2013}

Habermas, J. (2012). Teoria do Agir Comunicativo - Tomo 1: Racionalidade da ação e racionalização social. São Paulo: Martins Fontes.

Honneth, A. (1995). The struggle for recognition. The moral grammar of social conflicts. Oxford, UK: Polity Press.

Lara, R. S., \& Gheller, S. (2013). Webradio Migrantes: Canais em português e espanhol dão visibilidade para os coletivos de imigrantes latino-americanos. $8^{\circ}$ Mutirão Brasileiro de Comunicação. Natal (RN).

Lecomte, R. (2013/5). Expression politique et activisme en ligne en contexte autoritaire. Une analyse du cas tunisien. Réseaux (181), 51-86.

LEMEP, L. d. (2016, August 10). Metodologia. Retrieved from Manchetômetro: http:// www.manchetometro.com.br/metodologia/

Lima, V. A. (2006). Uma iniciativa fundamental. In I. C. Social, Vozes da Democracia: histórias da comunicação na redemocratização do Brasil (pp. 12-15). São Paulo: Imprensa Oficial do Estado de São Paulo; INTERVOZES: Coletivo Brasil de Comunicação Social.

Lima, V. A. (2013). Mídia, rebeldia urbana e crise de representação. In E. Maricato [et al], Cidades Rebeldes: Passe Livre e as manifestações que tomaram as ruas do Brasil (pp. 89-94). São Paulo: Boitempo: Carta Maior.

Lundby, K. (2009). Mediatization. Concept, changes, consequences. New York: Peter Lang.

McQuail, D. (1994). Mass communication theory: An introduction (3rd ed.). Thousand Oaks: Sage.

Miguel, L. F. (2014). Democracia e Representação. Territórios em Disputa. São Paulo: Editora Unesp.

Miguel, L. F., Biroli, F., \& Duailibe, K. (2013). O lugar do pobre no jornalismo brasileiro. $5^{\circ}$ Congresso da Associação Brasileira de Pesquisadores em Comunicação Política. Curitiba, PR.

Muhlmann, G. (2004). Du journalisme en démocratie. Paris: Éditions Payot \& Rivages. 
Müller, L. (2014). Comparing Mass Media in Established Democracies. Patterns of Media Performance. UK: Palgrave Macmillan.

Navarro, E. F. (2016). How is social media contributing to subjectivity in authoritarian societies? The case of \#YoSoy132 in Mexico. Observatorio.

Nelson, T., Clawson, R., \& Oxley, Z. (1997). Media framing of a civil liberties conflict and its reflects on tolerance. American Political Science Review, 91(3), 567-583.

Otre, M. A. (2015). A pesquisa acadêmica sobre comunicação popular, alternativa e comunitária no Brasil: análise de dissertações e teses produzidas em programas de Pós-Graduação em Comunicação entre 1972-2012. Tese (Doutorado em Comunicação Social). São Bernardo do Campo: Instituto Metodista de Ensino Superior.

Paiva, R., Malerba, J. P., \& Custódio, L. (2013). “Comunidade gerativa” e "comunidade de afeto": Propostas conceituais para estudos comparativos de comunicação comunitária. Revista Interamericana de Comunicação Midiática, 12(24), 244-261.

Passe Livre SP, M. (2013). Não começou em Salvador, não vai terminar em São Paulo. In E. Maricato [et al], Cidades Rebeldes: Passe livre e as manifestações que tomaram as ruas do Brasil (pp. 13-18). São Paulo: Boitempo: Carta Maior.

Peruzzo, C. (1998). Comunicação nos Movimentos Populares. Petrópolis: Vozes.

Peruzzo, C. (2006). Revisitando os conceitos de comunicação popular, alternativa e comunitária. XXIX Congresso Brasileiro de Ciências da Comunicação. Brasília, DF: Intercom : UnB.

Peruzzo, C. M. (2008). Conceitos de comunicação popular, alternativa e comunitária revisitados. Reelaborações no setor. Palabra Clave, 11(2).

Pleyers, G. (2010). Alter-Globalization. Becoming Actors in the Global Age. Cambridge: Polity Press.

Pleyers, G. (2018). Movimientos sociales en el siglo XXI : perspectivas y herramientas analíticas. Ciudad Autónoma de Buenos Aires: CLACSO.

Ponce Lara, C., \& Miranda, N. (2016). Redes de confianza online y flash mobs. Observatorio. 


\section{Media practices in the Brazilian mobilizations of 2013}

Reese, S. (2001). Framing public life: A bridging model for media research. In S. Reese, O. Gandy, \& A. Grant, Framing public life (pp. 7-31). Mahwah: Erlbaum.

Reporters Without Borders / Intervozes. (2017). Media Ownership Monitor. Retrieved February 20, 2018, from Media Ownership Monitor Brazil: https://brazil.momrsf.org/br/

Rodríguez, C., Ferron, B., \& Shamas, K. (2014). Four challenges in the field of alternative, radical and citizens' media research. Media, Culture and Society, 1-17.

Rosembach, C. J., \& Zottis, J. (2013). Comunicação Comunitária Alternativa. $8^{\circ}$ Mutirão Brasileiro de Comunicação. Natal (RN).

Rovira, G. (2013). Activismo mediático y criminalización de la protesta: Medios y movimientos sociales en México. Convergencia(61), 35-60.

Sartoretto, P. M. (2016). Between opportunities and threats - an analysis of Brazilian Landless Workers' movement experiences with new media technologies. Observatorio.

Secco, L. (2013). As Jornadas de Junho. In E. Maricato [et al], Cidades Rebeldes: Passe Livre e as manifestações que tomaram as ruas do Brasil (pp. 71-78). São Paulo: Boitempo : Carta Maior.

Serpa, A. (2013). L’univers des radios communautaires à Salvador de Bahia. Brésil(s) Sciences Humaines et Sociales. Dossier: Hétérotopies urbaines, 3, 89-108.

Sousa Santos, B. d. (2007). Beyond abyssal thinking: from global lines to ecologies of knowledges. Review.

Suzina, A. C. (2016). Digital resources in popular media practices in Brazil: strategies to reduce asymmetries in the public debate. Observatorio $\left(O B S^{*}\right)$ Journal $\left(\mathrm{n}^{\circ} 10\right.$, Special Issue. Media, Internet and Social Movements in the context of asymmetries), 11-34.

Suzina, A. C. (2018). Popular media and political asymmetries in the Brazilian democracy in times of digital disruption. 482 p. Louvain-la-Neuve: Université catholique de Louvain.

Suzina, A. C., \& Pleyers, G. (2016). Media practices and the challenge of political asymmetries. Observatorio $\left(\mathrm{OBS}^{*}\right), 10$ (ESPECIAL), 1-10. 
Treré, E. (2011). Studying media practices in social movements. CIRN Prato Community Informatics Conference 2011. Prato, Italy.

TV Cultura, F. P. (2013, August 05). Programa Roda Viva. São Paulo, São Paulo, Brasil.

Vieira Jr., V. (2007, October 08). Oligopólio na comunicação: um Brasil de poucos. Retrieved December 26, 2013, from Observatório do Direito à Comunicação: $\quad$ http://www.direitoacomunicacao.org.br/content.php?option=com docman\&task=doc details\&gid=342\&Itemid=99999999

Wolton, D. (2005). Il faut sauver la communication. Paris: Éditions Flammarion. 